\title{
Critical Success Factors for Online Distance Learning in Higher Education: A Review of the Literature
}

\author{
Bussakorn Cheawjindakarn ${ }^{1}$, Praweenya Suwannatthachote ${ }^{2}$, Anuchai Theeraroungchaisri ${ }^{3}$ \\ ${ }^{1}$ Faculty of Education, Chulalongkorn University, Bangkok, Thailand \\ ${ }^{2}$ Faculty of Pharmaceutical Sciences, Chulalongkorn University, Bangkok, Thailand \\ Email: bussakornonline@gmail.com, praweenya@gmail.com, anuchai@gmail.com
}

Received 2012

\begin{abstract}
The aim of this paper is to specify the Critical Success Factors (CSFs) for Online Distance Learning (ODL) in Higher Education (HE). Research methodology was analyzing and synthesizing the literature review. The literatures were reviewed to determine items relevant to online learning success as implementation, criteria and indicator. A total of 19 papers, published during 2000-2012, were selected from Chulalongkorn University reference databases. Data analysis method was using one of the popular analysis techniques for qualitative research works or the content analysis. The results on the CSFs for ODL can be grouped into 5 factors: 1) institutional management, 2) learning environment, 3) instructional design, 4) services support and 5) course evaluation. Each of these 5 factors includes several important elements that can assist to enhance efficiency of online learning courses in higher education institutions. It is a concrete approach to lead functions of an online institute or course in all levels to the same directions for achieving the success of the institute's vision, and make staffs and executives know what they have to do for the success of online distance learning.
\end{abstract}

Keywords: Critical Success Factor; Online Learning; Distance Education; Higher Education

\section{Introduction}

The growth in information technology (IT) rapidly changed the world. Accordingly, the teaching and learning in universities are adapted to keep up with the changes in communications and information technology for the development of quality education. This is to accommodate stakeholder groups (e.g. students, instructors, institute administrators, technical staffs, team producers, etc) to involve in their educational institutions. The internet has been used as a powerful tool to increase the accessibility to education for people around the world. Universities utilize and integrate forms of online learning, which requires access to the internet, as a new pedagogy form is different from traditional ones. "Online learning occurs in response to distance education” (Malithong, 2005: 203). Online learning, also known in another terms as "e-Learning", is the delivery of course content via electronic media (Khan, 2001; Harasim, 2003). Many higher education institutions are seeing the move on to e-Learning that had saved cost by merging traditional courses with online learning innovations (Selim, 2005; Rudestam \& Schoenholtz, 2010: 370). It will be interesting to see how the increased use of online learning will fully affect distance education enrolments in institutions (Bates, 2005: 13-14).

Therefore, the study of factors that affect critical success for ODL is important for many stakeholder groups. There are several factors need to be considered when developing and implementing for the success of distance learning in online courses.

\section{Literature Review}

\section{Online Distance Learning}

ODL is one of the new learning trends; a learning approach widely adopted in academic institutions. The majority of, if not all, instruction takes place online and there are no requirements for face-to-face meetings between students and instructors, either in the classroom or via video during the course (Arabasz \& Bake, 2003: 2). ODL technologies allows the delivery of learning resources or communications between instructors and students which may be applied either to the learning technology itself, or to online pedagogical methods (Catherall, 2005: 2, 196). Online courses are defined as having at least $80 \%$ of the course content delivered online, typically, with a little or none face-to-face learning (e.g. course management system (CMS), video conferences, etc) (Arabasz \& Bake, 2003: 2; Moore \& Kearsley, 2005; Allen \& Seaman, 2005: 4; Puteh, 2008; Kocur \& Kosc, 2009: 21; Charmonman, 2006: 6-7). Online learning is a combination of courses delivered through a CMS or webbased and print-based texts and workbooks. Learning is facilitated by an instructor who keeps in touch with students through the online conferencing system and e-mail (Niagara College Canada, 2012) that occurs in the human-computer interaction, allows access to content and educational tools and, if well done, can encourage development of a much more detailed and sophisticated understanding. (Rudestam \& Schoenholtz, 2010: 194-198). The benefits of ODL include: 1) 24 hour access to information, 2) up-to-date content materials, 3) self-paced learning, 4) customized courses, and 5) cost effectiveness (Puthe, 2008: 6)

Thus, it appears to be overwhelming and help to explain why institutions alike have factors to success as part of their strategies of online learning.

\section{Critical Success Factors}

CSFs first appeared in the literature in the 1980s when there 
was interest in the reason why some organizations appeared to be more successful than others, and research was carried out to investigate the components of these success factors (Ingram, Biermann, Cannon, Neil \& Waddle, 2000; Selim, 2007: 397; Puri, 2011: 1502). Therefore, CSFs are necessary for an organization or project to achieve its mission. These are different from other factors, which are "important" or "nice to have" but not necessary (Bacsich, Bastiaens \& Bristow, 2009: 90). However, CSFs must be done if a company need to be successful (Freund, 1988). According to a study by Rockart (1979), the CSFs approach has been established and popularized over the last 30 years by a number of researchers, particularly.

In many literatures, CSFs are defined as "the limited number of areas in which results, if they are satisfactory, will ensure successful competitive performance for the organization" (Daniel, 1961 \& Anthony et al., 1972 cited in Rockart, 1979: 85). Bruno \& Leidecker (1984: 24) defined CSFs are "characteristics, conditions or variables that, when properly sustained, maintained, or managed, can have a significant impact on the success of a firm competing in a particular industry". In addition, CSFs are also defined as "those factors addressed significantly to improve project implementation chances (Pinto \& Slevin, 1987 cited in Amberg, Fischl \& Wiener, 2005: 22). According to Rockart (1979: 87) who seeked to identify an ideal match between environmental conditions and business characteristics for a particular company, the following benefits exist for managers when applying the CSFs approach: "The process helps the manager to determine those factors on which he or she should focus management attention. It also helps to ensure that those significant factors will receive careful and continuous management scrutiny".

Thus, the fruit from the attempt to identify CSFs is a clear definition. CSFs are factors or variables that are important and indispensable especially in education institutes. These CSFs can assist the online stakeholder groups to be guided in their operation in order to achieve the institution's vision. Without the CSFs, the vision would not be responded.

\section{Basic Concept of Critical Success Factors for Online Distance Leaning}

CSFs for ODL are the areas that must be critically taken care of if institutions that needs success. The successful and sustained adoption makes it necessary for an effective combination of pedagogies, technologies and management of resources.

There are many CSFs describe to be for ODL courses. Volery \& Lord (2000) had surveyed on 47 students enrolled in an online based management course at an Australian University and identified three CSFs in online education: 1) technological factors (ease of access and navigation, level of interaction and interface design, etc), 2) instructors' characteristics (attitudes towards students, teaching style, technical competence, encourage classroom interaction, etc), and 3) students' characteristics (previous use of technology from a student's perspective). Papp (2000) explored distance learning from a macro perspective and suggested some CSFs that can assist faculty and universities in online environment development as 1) intellectual property, 2) suitability of the course for e-learning environment, 3 ) building the e-learning course, 4) e-learning course content, 5) e-learning course maintenance, 6) e-learning platform, and 7) measuring the success of an e-learning course. Govindasamy (2002) discussed seven e-learning quality benchmarks to provide a pedagogical foundation or a prerequisite for successful e-learning implementation namely, 1) institutional support, 2) course development, 3) teaching and learning, 4) course structure, 5) student support, 6) faculty support, and 7) evaluation and assessment. Allen \& Seaman (2005) annually surveyed online learning quality pillar of The Sloan Consortium and understood the foundation for assessing quality of online learning beyond the U.S. borders. The Sloan quality factors were: 1) access, 2) learning and effectiveness, 3) student support, 4) cost effectiveness, and 5) faculty satisfaction. Based on students' perceptions, Selim (2007) classified the CSFs for e-learning into four factors, namely, 1) instructors' characteristics (teaching style, attitude toward students, technology control, etc), 2) students' characteristics (motivation, technical competency, perception of content and system, collaboration in interaction, etc), 3) technology infrastructure (ease of access, internet speed, screen design, etc), and 4) institution support (technical support, computer availability, learning material accessibility and printing, etc). Vaye-U-Lan (2007) stated that resources that support e-Learning include 1) human resources, 2) computer and internet technology resources, and 3) e-Learning contents resources. Chantanarungpak (2010) synthesized the success indicators of e-learning system for higher education institutions in Thailand and found that the factors were: 1) media and technology, 2) institution and management, 3) instructional design, 4) supporting factors, and 5) evaluation components.

From the above-mentioned details, it is apparent that there are numerous factors affecting online learning implementation success that can assist higher education institutions in increasing the efficiency and effectiveness of adoption online learning process. Consequently, this study will seek for the appropriation of CSFs to guide the use of ODL in HE.

\section{Method}

The main purposes of this study were to specify the CSFs for ODL in the context of HE. The literatures were reviewed to determine items relevant to CSFs for ODL. The topics of interest were implementation, criteria and indicator for the success of ODL. A total of 19 papers, published during 2000-2012, were selected from Chulalongkorn University reference databases. The research instrument was data analyzing form. The methodology for this research were analyzing and synthesizing data using one of the popular qualitative techniques with content analysis.

\section{Finding}

The result from data analysis and synthesis method of literature review is to specify the CSFs for ODL within environment in HE. It can be grouped into 5 factors: 1) institutional management, 2) learning environment, 3) instructional design, 4) services support and 5) course evaluation. Each factor included several elements that can be explained as follows:

\section{Factor 1 Institutional Management}

Institutional management is significant for the success of the particular management level involve (Rockart, 1979: 87). These are business-driven processes that have perspective and focus on the issues affecting the organization (e.g., business administration, academic affairs, student services, etc). Therefore, online learning courses need to have their programs planned carefully (Pawlowski, 2002; ENQA, 2005; Puri, 2012) by includeing the following elements: 
- Market Research - Market research is the analysis on target group requirements, which must be executed discreetly from the central of educational institute with awareness of ODL (Pawlowski, 2002; ENQA, 2005; Puri, 2012). Moreover, the data from market research have to be updated annually or before the planning of a major event (Bacsich, Bastiaens \& Bristow, 2009).

- Program Framework - The management of the institution is to determine the framework and scope of the program as related to the definitions used in the operation. This may be the policies and procedures: philosophy, mission, copyright requirements, and intellectual property (Cruz, 2010; Chantanarungpak, 2010). This factor is being developed as it is needed to accommodate changes in the organization's strategy (Rockert, 1979), as direction for implementing the online course in order to support the students' progress (ENQA, 2005).

- Operational Plan - This factor is the management style of the institution which is the integration of online learning into the curriculum as a whole (Bacsich, Bastiaens \& Bristow, 2009). Construction of program development plans at both the short and long term operation plan (Selim, 2005, 2007) to enhance and improve an appropriate mix of academic and business/marketing activities, e.g., methodology announcement, admission criteria, online payment system, etc (Pawlowski, 2002; Chantanarungpak, 2010; Cruz, 2010).

- Cost Effectiveness - To be fully implemented, the online learning course will need a budget to be significant enough to invest in the course (Puri, 2012). The budgets for online learning systems are the high investment costs and longterm sustainability (ENQA, 2005; Chantanarungpak, 2010). Therefore, costs must be property to be used by all online courses in order to gain the right to charge for online classes (Bacsich, Bastiaens \& Bristow, 2009; Puri, 2012). Apart from institutions' needs to develop their services, there are also needs to reduce costs as well (Harasim, 2003; Allen \& Seaman, 2005). However, advancements in information technology are perceived by universities as the solution to the quality and cost problem (Selim, 2005: 340).

\section{Factor 2 Learning Environment}

Online learning environment refers to the locations where students access online resource, use systems for access to online course and communication, obtain tutor assistance, and receive assessment (Lennon \& Maurer, 2003 cited in Bhuasiri \& et al, 2012). Online learning environment also includes instruction and university support (Selim, 2007). People learn best in a learning environment that is supportive, relaxeing and casual. Thus, the learning environment should be comfortable in all aspect such as the physical, trust, respect, helpfulness and freedom (Wands and Blanc, 2001). However, online learning environment does not have a high effect on learning outcomes but it has the potential to develop appropriate learning environment in an online learning course.

- Course Management System (CMS) - Also known as Learning Management (LMS) is taking on similarly important role to several of $\mathrm{HE}$ administrative function (e.g., finance, human resource, etc). At the micro level, CMS/LMS usually facilitates student registration, the delivery and tracking of online learning courses and content, and testing, and may also allow for the management of instructor-lead training classes. CMS/LMS provides to an in- structor a set of tools and a framework that allow the relatively easy creation of online course content and the subsequently teaching and management of that course including various interactions with students talking the course. (Pawlowski, 2002; ENQA, 2005; Selim, 2005, 2007; Masrom, Zainon \& Rahiman, 2008; Chantanarungpak, 2010).

- Technical Infrastructure - Technology plays important roles in delivering learning outcomes because students have more interactions in online learning environments that are essential to be successful (Wands \& Blanc, 2001; Selim, 2005: 340; Bhuasiri \& et al, 2012). University must have supportive quality technology with a modern and appropriate in transfer knowledge for online courses (Wands \& Blanc, 2001; Harasim, 2003; Masrom, Zainon \& Rahiman, 2008; Mosakhani \& Jamporazmey, 2010). To have the students facilitated, the most simple and easiest access to learning must be supplied (Selim, 2005, 2007; Cruz, 2010, Chantanarungpak, 2010). The efficient and effective use of IT in delivering online learning base components of a course is of critical importance to the success and student acceptance of online learning. To ensure that the university IT infrastructure is rich, reliability in and capability of providing the courses with the necessary tools to make the delivery process as smooth as possible are critical to the success of online learning (Selim, 2005: 341). This factor is associated with the hardware and software technology including high speed internet connection, bandwidth for download audio and video, system reliability and availability, system backup procedures, network security, courseware authoring applications, system response, and etc (Wands and Blanc, 2001; ENQA, 2005; Selim, 2005, 2007; Bhuasiri \& et al, 2012; Puri, 2012).

- Interactive Learning - Effective online learning environments require some forms of interaction and collaboration among students as well as between learners and instructors. Moore \& Kearsley (2005) identified three types of interactions: 1) learner-content interaction, 2) learner-instructor interaction, and 3) learner-learner interaction. However, interactive learning must be relevant and appropriate to the purpose of instruction to increase learners' participation in educational activities (Wands and Blanc, 2001), such as the appropriate use of multimedia to convey highly interactive learning. Most studies indicate that learner-learner interaction is CSF when their satisfaction with online learning based courses is measured (Phillips \& Peters, 1999; Selim, 2005).

- Access and Navigation - Interface design is a technical support to facilitate communication and learning activities of online course (Volery \& Lord, 2000; Harasim, 2003; Penn State, 2008). Students can easily access to enhance the learning experience in the context of the online environment, e.g., quickly web access (Wands \& Blanc, 2001; Selim, 2005, 2007; Allen \& Seaman, 2005). Accessibility requirements of the course are to adhere to the policy of the University. Moreover, navigation is concerned with the visual structure to help students quickly find programs and content whilst the online course design should be easy to be consistent and screen navigation system (Penn State, 2008). These relate to the look and feel of the online learning that require good interface designs that are user friendly (Wands \& Blanc, 2001; Puri, 2012), such as pointers or marquees leading to useful information "What You See Is What You 


\section{B. CHEAWJINDAKARN ET AL.}

Get” (WYSIWYG) (Wands \& Blanc, 2001)

\section{Factor 3 Instructional Design}

Pedagogical for online learning focuses on the learning and teaching that enhance the mood (Puri, 2012), e.g., assignments options, interactive course, learning styles, multimedia tools, technologies. As instructor is a facilitator for student commitment includes element the following:

- Clarification of Objectives - The purpose of online learning, like any other learning approach, is to achieve the learning objectives. Therefore, online learning course must have clear learning goals and objectives at the very beginning phase of the learning. Students should be able to easily access course syllabus, contains information on the program which clarify principle to learning content and using tools. In addition, clearly defined learning pathway is the required structure to allow the students to choose their own path and reflect the learning needs (Wands \& Blanc, 2001; Penn State, 2008; Cruz, 2010).To indentify learning outcome is a learning standard related to students' skills and achievement, both evaluation the methods and the condition what the students want to learn and able to do at the end of the course

- Content Quality - Content issue is a strong pedagogical foundation. Well-designed and selected courses content and learning material facilitate meaningful educational experiences that are essential for implementation of online learning materials (e.g., accuracy, completeness, ease of understanding, timeliness, relevance and consistency) (ENQA, 2005; Selim, 2005, 2007; Masrom, Zainon \& Rahiman, 2008; Mosakhani \& Jamporazmey, 2010; Bhuasiri \& et al., 2012). The content quality of writing, images, video, or flash to meets generally accepted standard of semantics, style, grammar, and knowledge (Bhuasiri, 2012).

- Learning Strategies - Educational institutions have a wide range of strategies to support teaching and learning. Especially, instructor plays a central role in creating the effectiveness and success of distance learning based courses that support the "student-centered" principle. For example, student is a user control of screen information by their owns, and also enter information when they do learning activities (Wands \& Blanc, 2001). Therefore, it is essential that institutions must prepare in various ways to encourage instructors to teach and students to study in the online course, such as integrating technology into appropriate learning strategies (Harasim, 2003; Bacsich, Bastiaens \& Bristow, 2009, Chantanarungpak, 2010).

- Psychology of Learning - To enhance the students' learning skills through practical experiences in the online learning system, students must be motivated and committed by themselves or by the instructions from teachers (Wands \& Blanc, 2001). In addition, students will learn better if they are motivated to learn in the first place (Pawlowski, 2002). Moreover, the reinforcement will create awareness; for example, the rewards from a student's efforts make that student want to repeat the behavior. Transmission is dependent on the performance of students with new learning skills that can be applied directly in the workplace (Wands \& Blanc, 2001). Instructor' feedback should be made available in the forms of immediate and adequate after students have attempted on online interaction (Wands \& Blanc, 2001; Pawlowski, 2002; Selim, 2005, 2007; Penn State, 2008; Bacsich, Bastiaens \& Bristow, 2009).
- Learning Assessment - The effective assessment of learning is to evaluate and measure benefits resulting from online learning implementation at a particular institution (ENQA, 2005) that will be done after their completing the course (Wands \& Blanc, 2001; Puri, 2012). Students can learn effectively with cognitive development and learning approach development (Harasim, 2003). The assessment method must be valid, reliable, flexible and fair (e.g., test studies, tasks, etc) (Wands \& Blanc, 2001; Pawlowski, 2002; Masrom, Zainon \& Rahiman, 2008; Chantanarungpak, 2010).

\section{Factor 4 Services Support}

ODL will not succeed in achieving their goals when it does not have access to technical advice and support. Institution's resources are factors that must be developed for the learning support services system (Harasim, 2003; Mosakhani \& Jamporazmey, 2010; Puri, 2012; Chantanarungpak, 2010). Service quality significantly influences students and instructors satisfactions and happiness in teaching and learning (Allen \& Seaman, 2005; Selim, 2005; Penn State, 2008; Bhuasiri, 2012). Services also include the provision of supports which include equipment accessibility and computer training that are important factors for online learning acceptance (Lee, 2008). In addition, services include administrative concerns such as management, funding, maintenance, and the delivery of resources, are positively related to students' satisfaction and instructors' satisfaction (Ozkan \& Koseler, 2009).

- Training - This factor is the development of the characteristic of online stakeholder groups, especially students and instructors, by training on competencies and partner personal development which enable all stakeholders to efficient in online learning (Wands \& Blanc, 2001; Masrom, Zainon, Rahiman, 2008; Mosakhani \& Jamporazmey, 2010; Puri, 2012). The training that improves the ability of people relates to technology and differently interactive learning (Selim, 2005, 2007; Bacsich, Bastiaens \& Bristow, 2009). These are key factors for faculty to implement online learning in developing course (e.g., computing skills, technical background, training programs, and etc). In addition, instructors are suggested to be enthusiastic to motivate the students and to enhance students' computing literacy and online learning applications skills (e.g., e-mail, presentation, and creative thinking) (Selim, 2005). These things can satisfy online stakeholders and make them feel like using the new method (Cruz, 2010).

- Communication Tools -Communication resources are used to supporting the interaction between teachers and students (e.g.,e-mail, chatroom, webboard, etc) (Pawlowski, 2002; Penn State, 2008; Puri, 2012). The facilitated communication contributes to consistence in line with expected learning outcomes (Allen \& Seaman, 2005; Bhuasiri \& et al., 2012). However, the tools used depend on the strategic goals, the objectives of the communication program, the profile of the target audience, the various advantages and disadvantage of each tool, and the communications budget. Therefore, it is important to know how to use the community tools option in order to choose appropriate the tools in the online learning (Moore, Deane \& Galyen, 2011: 129).

- Help Desk - To establish student help desk is the best way to assist student (Bacsich, Bastiaens \& Bristow, 2009). Online course provides access to useful facilities. This includes both offline and online resources. The "offline" resource can 
be just a paper manual to help learning. On the other hand, "online" support is not only just an electronic manual but also an option to help the students who request for direct assistance, such as terminology and glossary (Puri, 2012). Moreover, there must also be human resources, e.g., expert users, trainers, to give technical assistances and advice (Wands \& Blanc, 2001).

\section{Factor 5 Course Evaluation}

This factor is the assessment of the success in the online implementation. All phases provide a measure of quality assurance for online courses in order to serve the online learning needs of institution. (ENQA, 2005; Masrom, Zainon \& Rahiman, 2008; Bhuasiri; 2012). Evaluation is the key to quality online learning, and having a plan for the process is the key to evaluation. Course evaluation includes formative evaluation in project management and summative evaluation in implementation plan. Evaluation process must cover all aspects the online course, to ensure that ODL systems achieve the objectives of the course. (Pawlowski, 2002; ENQA, 2005; Chantanarungpak, 2010; Musa \& Othman, 2012; Puri, 2012). This is the final step to ensure that online learning applications are not a barrier to learning.

\section{Conclusions}

ODL is rapidly becoming a popular mode of study among students worldwide. This trend is also visible in universities, with the emergence of several higher education distance learning institutions using online learning to support its learning activities. Therefore, identifying CSFs is necessary to determine the direction of an online course which must be implemented if organization wants to be success.

In conclusion, the "CSFs for ODL in HE" found from a review of the literature are: 1 ) institutional management - market research, program framework, operational plan, cost effectiveness, 2) learning environment - course management system, technical infrastructure, access and navigation, 3) instructional design - clarify of objectives, content quality, learning strategies, psychology of learning, learning assessment, 4) services support - training, communication tools, help desk, and 5) course evaluation.

It is suggested that each of these 5 factors is important to enhance efficiency of online distance learning courses. It is a concrete approach to lead functions of an online institute or course in all levels to the same directions for achieving the success of the institute's vision, and make staffs and executives know what they have to do for the success of ODL.

\section{Implication/Future Work}

This finding is phase one in the process of the dissertation, "Strategic management of educational technology and communications center based on critical success factors for online distance learning in higher education: A multi-case study". The future work is to explore consistency between "CSFs for ODL in HE” and "organization function of Educational Technology Center" and next, to study and synthesize strategic management of educational technology center based on CSFs for ODL in HE.

\section{Acknowledgements}

I would like to express my sincere thanks to my thesis advi- sor and co-adviser for the invaluable help and constant encouragement throughout the course of this research.

\section{REFERENCES}

Allen, I. E. \& Seaman, J. (2005). Growing by Degrees: Online education in the United States, 2005. The Sloan Consortium. URL (last checked 17 June 2012) http://sloanconsortium.org/publications/ survey/growing_by_degrees_2005

Amberg, M., Fischl, F. \& Wiener, M. (2005). Background of critical success factor research. Friedrich-Alexander-Universitat Erlangen-Nurnberg Working, Paper No 2/2005. Nurnberg, Germany.

Arabasz, P. \& Bake, M.B. (2003). Evolving campus support models for e-Learning courses. ECAR Respondent Summary, March 2003. URL (last checked 28 Dec 2011) http://net.educause.edu/ir/library/pdf/EKF/ekf0303.pdf

Bacsich, P., Bastiaens, T. \& Bristow, S.F. (2009). Reviewing the virtual campus phenomenon: The rise of large-scale e-Learning initiatives worldwide. Heverlee: EuroPACE ivzw. URL (last checked 19 Jan 2012)

http://revica.europace.org/Re.ViCa\%20Online\%20Handbook.pdf

Bates, T. (2001). National strategies for e-learning in postsecondary education. Paris: UNESCO: International Institute for Educational Planning. URL (last checked 17 Jan 2012) http://unesdoc.unesco.org/images/0012/001262/126230e.pdf

Bruno, A.V. \& Leidecker, J.K. (1984). Identifying and using critical success factors. Long Range Planning, 17, 23-32.

Bhuasiri, W.; Xaymoungkhoun, O.; Zo, H. \& Rho, J. (2012). Critical success factors for e-learning in developing countries: A comparative analysis between ICT experts and faculty. Computers \& Education, 58, 843-855.

Catherall, P. (2005). Delivering e-learning for information services in higher education. Chandos Publishing: Oxford.

Chantanarungpak, K. (2010). Development of success indicators of e-Learning system for higher education institutions in Thailand. Ph.D. Thesis, Bangkok: Chulalongkorn University.

Charmonman, C. (2006). Growing by degrees online education in the United State, 2005. Bangkok, Assumption publishing.

Cruz, A. \& Implementation and Support Manager. (2010). Key success factors for eLearning implementation resulting from proper planning. URL (last checked 31 Dec 2011)

http://www.shiftelearning.com/key-success-factors-for-elearning-imp lementation-resulting-from-proper-planning/

Esteves, J. (2004). Definition and analysis of critical success factors for ERP implementation projects. Doctoral Thesis at the Universitat Politecnica de Catalunya, Barcelona.

European Association for Quality Assurance in Higher Education (ENQA). (2005). Standards and Guidelines for Quality Assurance in the European Higher Education Area.

Freund, Y.P. (1988). Critical success factors. Planning Review, 16(4), 20-25.

Govindasamy, T. (2002). Successful implementation of e-Learning; Pedagogical considerations. The Internet and Higher Education, 4(3-4), 287-299.

Harasim, L. (2003). Elearning communities of practice for teachers. In the electronic classroom of tomorrow. Columbus, Ohio: EOS Publishing.

Ingram, H., Biermam, K., Cannon, J., \& Niel \& Waddle, C. (2000). Internalizing action learning: a company perspective. Establishing critical success factors for action learning courses. International Journal of Contemporary Hospitality Management, 12(2), 107-113.

Khan, B.H. (2001). A framework for web-based learning. New Jersey, USA: Educational Technology Publication, Engelwood Cliffs.

Kocur, D., \& Kosc, P. (2009). E-learning implementation in higher education. Acta Electronica et Information, 9(1), 20-26.

Lee, Y. C. (2008). The role of perceived resources in online learning adoption. Computers \& Education, 50(4), 1423-1438.

Lincharearn, A. (2012). Qualitative data analysis techniques. Journal of Educational Measurement, Faculty of Education, Naresuan Univer- 
sity, 17(1), July 2012, 17-29.

Malithong, K. (2005). Technology and Communication for Education. Bangkok, Aroon printing.

Masrom, M., Zainon, O. \& Rahiman, R. (2008). E-learning critical success factors: institutional and technological aspects. E-Learning Issues in Malaysian Higher Education, 49-63.

Moore, J.L; Deane, C.D. \& Galyen, K. (2011). e-Learning, online learning, and distance learning environments: Are they the same?. Internet and Higher Education, 4, 129-135.

Moore, M.G. \& Kearsley, G. (2005) Distance education. A systems view. Belmont, CA: Wadsworth.

Mosakhani, M. \& Jamporazmey, M. (2010). Introduce Critical Success Factors (CSFs) of elearning for Evaluating e-Learning Implementation Success. International Coriference on Educational and Information Technology, V1-224-V1-228.

Musa, M.A. \& Othman, M. S. (2012). Critical success factor in e-Learning: an examination of technology and student factors. International Journal of Advances in Engineering \& Technology, 3(2), 140-148.

Niagara College Canada. (2012). Continuing education online/ distance learning. Southern Ontario (Niagara Region), Canada. URL (last checked 7 Nov 2012) http://www.niagaracollege.ca/content/ContinuingEducation/OnlineL earning/WelcometoCEOnlineLearning.aspx

Nida. (2011). Case Study Implementing e-Learning at Nida. URL (last checked 26 Jan 2012)

http://y30.wikidot.com/scribe-book-9-4:case-study-implementing-e-l earning-at-nida

Oneill, K.; Singh, G. \& Donoghue, J. (2004). Implementing eLearning Programmes for Higher Education: A Review of the Literature. Journal of Information Technology Education, 3, 313-323.

Ozkan, S., \& Koseler, R. (2009). Multi-dimensional students' evaluation of e-learning systems in the higher education context: an empirical investigation. Computers \& Education, 53(4), 1285-1296.

Papp, R. (2000). Critical success factors for distance learning. Paper presented at the Americas Conference on Information Systems. Long Beach, California, USA.

Pawlowski, J. M. (2002). Reusable Models of Pedagogical Concepts - a Framework for Pedagogical and Content Design. In Proceedings of ED-MEDIA 2002, World Conference on Educational Multimedia, Hypermedia \& Telecommunications.
Penn State. (2008). Penn State Quality Assurance e-Learning Design Standards. Web Learning @ Penn State, 1-11. URL (last checked 23 April 2012)

http://www.sc.edu/cte/larryragan/doc/designstandards.pdf

Phillips, M. R., \& Peters, M. J. (1999). Targeting rural students with distance learning courses: A comparative study of determinant attibutes and satisfaction levels. Journal of Education for Business, 74(6), 351-356.

Pinto, J. \& Slevin, D. (1987). Critical Factors in Successful Project Implementation. IEEE Transactionson Engineering Management, 34(1), 22-27.

Puri, G. (2012). Critical success Factors in e-Learning - An empirical study. International Journal of Multidisciplinary Research, 2(1), 149-161.

Puteh, M. (2008). E-Learning Concepts and Literature Review. E-learning issues in Malaysia higher education. In Mohd Fuad Mohd Salleh (editor). Universiti Teknologi Malaysia, 1-22.

Rockart, J. (1979). Chief Executives Define Their Own Information Needs. Harvard Business Review. March/April 1979, 81-92.

Rudestam, K. E. \& Schoenholtz read, J. (2010). Chapter 7 Globalization in Online Learning, American Distance Education Consortium (ADEC) and Sloan-C Quality Factors and Use of Online Learning as Strategies Asset. Handbook of Online Learning. ( $2^{\text {nd }}$ Edition). SAGE Publications, Inc., 187.

Selim, H. M. (2005). E-Learning Critical Success Factors: An Exploratory Investigation of Student Perceptions. Proceedings of Information Resources Management Association International Conference, USA, 340-346.

Selim, H. M. (2007). Critical success factors for e-learning acceptance: Confirmatory factor models. Computers \& Education, 49(2), 396-413.

Vate-U-Lan, P. (2007). Readiness of eLearning Connectivity in Thailand. Fourth International Conference on eLearning for Knowledge-Based Society, November 18-19, 2007, Bangkok, Thailand, 21.1-21.7.

Volery, T. \& Lord, D. (2000). Critical success factors in online education. The International Journal of Educational Management, 14(5), 216-223.

Wands, M. \& Blanc, A.L. (2001). Critical Success Factors: eLearning Solutions. 2(3), URL (last checked 9 June 2012)

http://www.internettime.com/itimegroup/crit_capp.htm 